\title{
CREATIVITY TRILATERAL DYNAMICS: PLAYFULNESS, MINDFULNESS, AND IMPROVISATION
}

\author{
Doaa KAMALELDIN HASSAN ${ }^{*}$ \\ Ain Shams University, Faculty of Engineering, Architecture Department \\ 1, El-Sarayat str., Abbassia 11517, Cairo, Egypt
}

Received 04 August 2018; accepted 20 January 2019

\begin{abstract}
As recent studies proved; creativity is no longer an option, it is really essential for our everyday life. In fact, creativity is a unified whole composed of four interweaved strands; creative person, creative press, creative process, and creative product. Nevertheless, creative person could be considered the motor of these unified gearwheels. Creative person should be open for novelty, tolerant for complexity and ambiguity as discussed through literature; however, the question here is how to acquire these characteristics. In this sense, issues of playfulness, mindfulness and improvisation could be much related and might answer such question. In fact, these topics were approached in many researches in relation to creativity, but there are scarce studies that might relate them to each other, i.e., playfulness with mindfulness, mindfulness with improvisation, or improvisation with playfulness. Thus, this research, as a contribution to the field of the psychology of creativity, proposes that there is a correlation among these three experiences or forces of a creative person. Then, the aim of this research is to explore these interrelations that, if boosted, might leverage creative person's characteristics. The methodology is based on inductive reasoning via two phases; first, analyzing literature on playfulness, mindfulness and improvisation and their relations to creativity studies. The second phase is traversing these three corpuses, sewing them together in order to create a braid of these forces to act as dynamics boosting for higher levels of creative mindset.
\end{abstract}

Keywords: creative mindset, creative person, creativity, improvisation, mindfulness, playfulness.

\section{Introduction}

All around the world, every day and even every minute, people keep coming up with great ideas and solving difficult problems. The ideas might not influence the world straightaway, but they might reach a few people. However, the only fact is that creativity could be described as human originality across the diverse activities of everyday life, at work and leisure, which is vital to human survival and could be possessed by everyone to some extent (Burnett \& Cabra, 2018).

*Corresponding author. E-mail: doaa.kamal@eng.asu.edu.eg

This is an Open Access article distributed under the terms of the Creative Commons Attribution License (http://creativecommons. org/licenses/by/4.0/), which permits unrestricted use, distribution, and reproduction in any medium, provided the original author and source are credited. 
In this respect, it is important to clarify that creativity does not refer only to the human aspect, the creative person, but also to the creative process, the creative product, and the creative press (climate). These are the 4Ps, the model of creativity (Miller, Vehar, Firestien, Thurber, \& Nielsen, 2011). “< . > the definitions form four strands. Each strand has a unique identity academically, but only in unity do the four strands operate functionally" (Rhodes, 1961, p. 307).

Despite the importance of the unity of these four strands of creativity, the creative person or the creative mindset could be seen as a core for realizing and developing the other strands. This point of view conforms to the investment theory that regards creativity as a decision; the one who takes the decision, in fact, is the person. This perspective of creativity as a decision, proposes that creativity can be developed. To be creative, one must first decide to generate new ideas, analyze then sell the ideas to others. More clearly, a person may have synthetic, analytical, or practical skills but not apply them creatively. Actually, we are all creative but we need to acquire the ability to switch between conventional and unconventional modes of thinking, we need to decide (Sternberg, 2006).

Therefore, we need to develop our creative mindset to reach applied unconventionality. Many researches discussed characteristics of the creative person. Some talk about being thorough, ethical, open-minded, emotional, risk taking, etc. Others proposed the concept of the Big Three. Those emphasized that there are three affective skills that underlie all steps of the creative problem solving (CPS), which are openness to novelty, i.e. the ability to entertain ideas that at first seem silly and risky; tolerance for ambiguity, that means to be able to deal with uncertainty and to avoid jumping to immature conclusions; and finally tolerance for complexity, which is the ability to stay open and persevere without being overwhelmed by the amounts and the interrelated and complex issues and daring perspectives (Murdock, Burnett, \& Mance, 2008).

In this sense, we need to explore the question: how can we reach these characteristics or skills? How can we decide to be more creative? How to be powerful enough to extract this intrinsic potency? Researches explained that playfulness, mindfulness and improvisation could be considered tools, forces or approaches to enhance the spirit of creativity, to make people discover and enhance their inner potentials to be more creative. Playfulness, mindfulness and improvisation are frequently mentioned and studied in relation to creativity studies. Many studies approached associations and effects of each of these domains on creative abilities and skills. However, very scarce or exceptional literature goes through mutual relations and effects among these forces. Accordingly, this research will traverse literature in order to explore more linkages among these forces. In this respect, the research hypothesis proposes that these linkages might be interrelated forming a unified footing for more creative mindset essential for everyday creativity in general and stepping forward for crossing the developmental trajectory of creativity, from mini $\mathrm{C}$, little $\mathrm{C}$ to pro $\mathrm{C}$ or even reaching big $\mathrm{C}$ of creative person (Figure 1) (Kaufman \& Beghetto, 2009). 


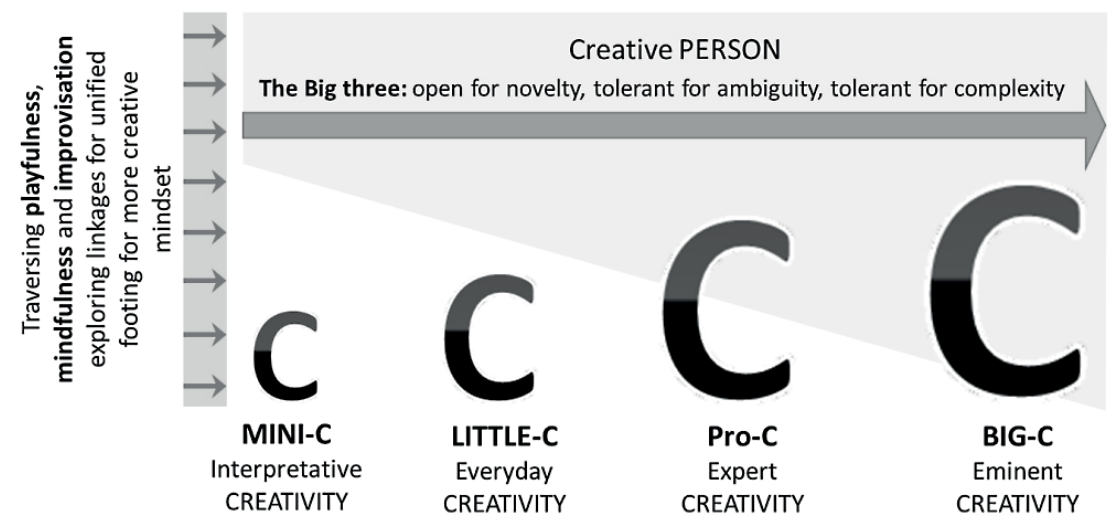

Figure 1. Boosting for crossing the trajectory of creativity (source: created by author)

\section{Study methodology}

This research is a qualitative study, inductive reasoning-based, that depends on analyzing literature to induce a new theory/concept that could be tested in other further researches. The study depends on two phases of analysis. First, literature on playfulness, mindfulness and improvisation exploring relations to creativity studies was analyzed. Second, these three corpuses were traversed via comparative analysis in order to reveal interrelations; and hence, sewing them together in terms of their relation with creativity in order to create a woven fabric of forces that act as dynamics boosting for higher levels of creative mindset (Figure 2).

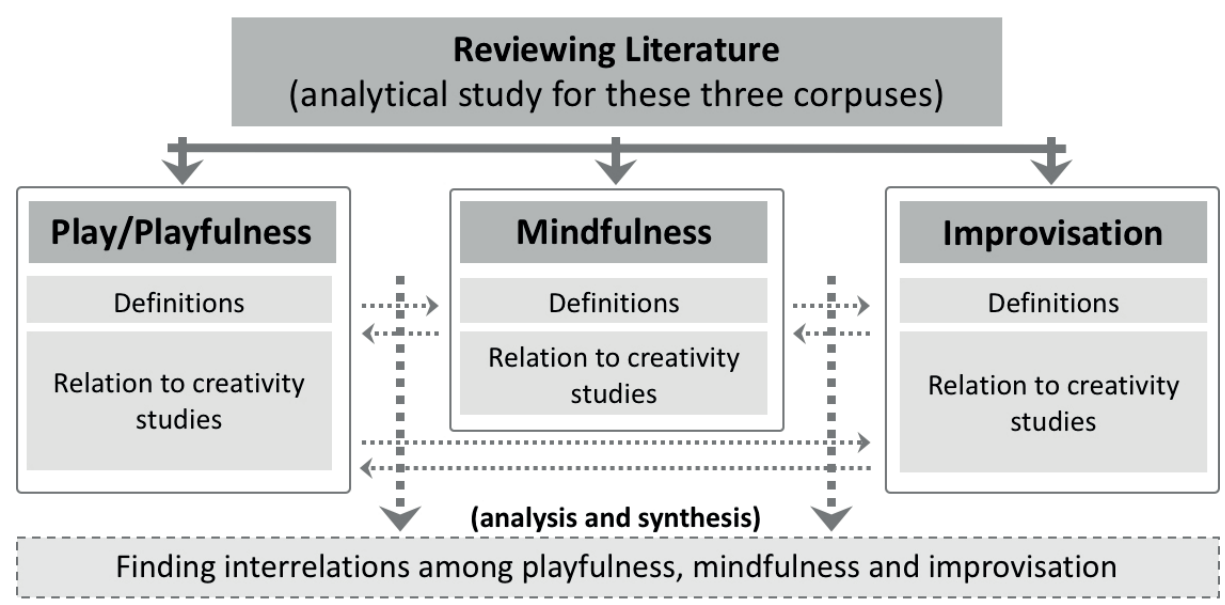

Figure 2. Study methodology plan (source: created by author) 


\section{Crossing the literature: the essence of playfulness, mindfulness and improvisation in relation to creativity}

In this section crossing literature about playfulness, mindfulness and improvisation in relation to creativity studies will be reviewed analytically. Every item will be studied as an autonomous entity to extract its definition, then it will be reviewed pursuing the relation to creativity to find the joint areas as presented in (Figure 2).

\subsection{Playfulness}

To dig into playfulness secrets, it is significant to start with the word "play". Is play a marginal issue, or is it crucial for our survival? In fact, we value our leisure time and can devote many hours and money to such activities as hiking, going for picnic trips or watching our kids swimming or playing tennis. On the other hand, we may see play as frivolity; we accept the reduction of playtime at school in favor of more hours for studying and testing. In fact, play is part of our evolutionary history; in other words, there is a drive to play and we are built to play (Brown \& Vaughan, 2009).

Defining playfulness: It is critical to define play the same way as we define a mobile, a cat, or even a flower. "Play" becomes an evaluative and emotive term like "art" or "love", carrying social, cultural, and aesthetic aspects that add to the challenge of defining the word. However, we could argue for play as an aspect or a function of human development. Psychiatrist and play advocate, Stuart Brown, argues that play is practice for the body, exercise for the feelings, and training for the mind (Eberle, 2014).

Play or playfulness is not a term associated only with children, but it is also significant for adults as the concept of development is not exclusive to children. In this respect, organizational behaviorists as Charalampos Mainemelis and Sarah Ronson (2006) have proposed that play can be well explained as a behavioral orientation. Play should not be limited to specific activities apart from work, because even work tasks can be executed playfully. In brief, many human activities including those we do every day at work could be done within a playful approach, i.e., remodeled into play (West, Hoff, \& Carlsson, 2016). "When we lack that feeling of lightness in what we do it should be $\langle\ldots\rangle$ as alarming as chest pain" (Brown \& Vaughan, 2009, p. 60).

Brown and Christopher Vaughan emphasize that play is a state of mind, rather than an activity (2009). From this point of view, we can create clearer vision about play; we can understand it in terms of its attributes or elements that constitute different emotional experiences. Through play, people experience interest, discovery, pleasure, knowledge, and creativity. These different experiences do not form a linear process; they are not phases that should be orderly completed. The experience of play involves these experiences in a more complicated relationship (Eberle, 2014).

Playfulness is a state of mind reflected in behavior in every tiny action. When you are immersed in this mood, you are open to experience pleasure, discovery, knowledge and creativity.

Playfulness and creativity: Reviewing literature and survey studies proved the association between playfulness and creativity. Playful activity is characterized by enhancing positive mood and, in turn, behavior, which helps in generating novel solutions to a problem. One of these studies shows that respondents to the survey who assessed themselves as acting playfully also reckoned that they came up with new ideas (Bateson \& Nettle, 2014). Other em- 
pirical studies on/by university students explored the influence of various types of play (such as video games and imaginative role-playing games) on creative performance. On the other hand, reframing situations or tasks by joyful mode could be approached via using contextual cues, such as games, toys, sweets, or simply through playful rearrangements of furniture to make the task more informal. In this sense, a consultant described how she uses candy to cue a playful environment: "I have always got sweets of various kinds with me - adults still associate 'sweeties' with children and somehow giving them sweets also gives them permission to let their 'inner children' out to play" (West et al., 2016). In brief, these findings support the hypothesis advanced by J. Nina Lieberman (1977), Patrick Bateson and Paul Martin (2013) that playfulness is associated with creativity.

As we get immersed in different emotional experiences through play, a unique state of mind is created, we then engage in an imagination mode. Play creates a suspension of reality drawing people to imagine (Kuschner, 2010), hence breaking the established patterns, thoughts or behaviors. In play activity, we experience without worrying about the real challenges. People who are open to new experiences are found to be more creative (Kumar, Roy, \& Sameer, 2017). In fact, the concept of imagination and suspension of reality lets individuals inhabit a new world; it is the state that boosts people to improvise (Henricks, 2014). Reflectively, experiencing creativity is a play. The creation of something new is not accomplished by the intellect but by the play instinct acting out of inner necessity. "The creative mind plays with the objects it loves" (Jung, 2016). Through play we can reach self-realization. Play is an exploration of powers and potentials. We play to find out what we can - and cannot - do and to see if we can extend our capabilities (Henricks, 2014). It really opens the door for creativity and develops mental flexibility characterized by the ability to search for variation and novel solutions (West et al., 2016).

Based on the aforementioned facts, playfulness can be seen as a CPS's much more entertaining cousin. If you want to create, you need to play. We need to be childlike not childish (Burnett \& Cabra, 2018). Playfulness can be viewed both as a state and a trait. Playfulness is a state of a joyful, stimulating and encouraging press that enhances immersion and being at the present moment; then it becomes a trait of a creative mindset (Gackenbach \& Bown, 2011). Therefore, it is really significant to enhance playfulness as a state and, in turn, as a trait. This could be reached via introducing specific activities (direct play) or reframing a situation or a task to make it more enjoyable (Figure 3).

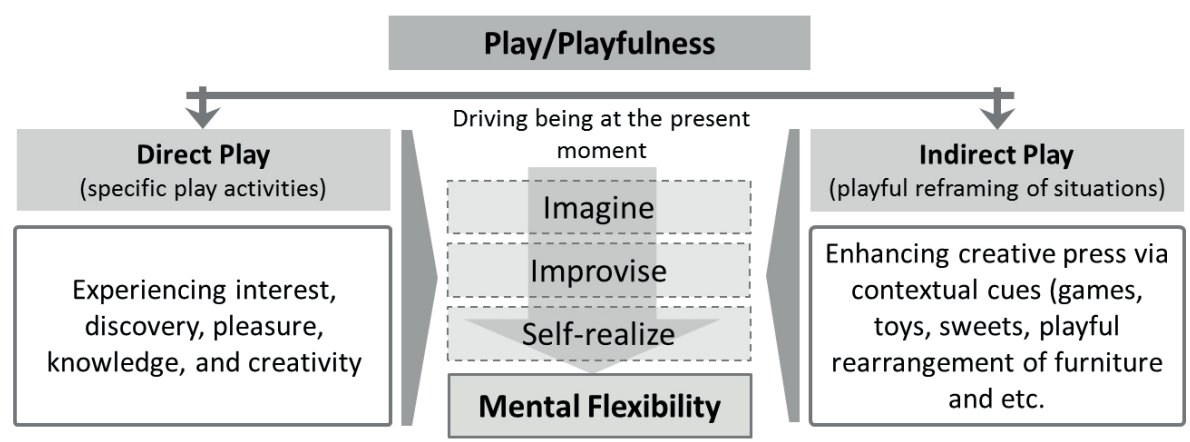

Figure 3. Playfulness framework for more creative mindset (source: created by author) 


\subsection{Mindfulness}

People have been applying mindfulness for thousands of years as a practice associated with various religious and secular traditions, but more recently, it is involved in non-religious meditation. In this sense, exploring mindfulness in terms of its relations to creativity is the focus here (Positive Psychology Program, 2017).

Defining mindfulness: Mindfulness is a "systematic training in knowing what is happening, while it is happening" (Nairn, 1999). It is about being fully immersed in the present moment. It is being curious, open, accepting, and aware, while experiencing with all of our senses. When we are mindful, we are focused on the present moment and allowing it to unfold its possibilities (Burnett \& Cabra, 2014). To be mindful we need to adopt specific attitudes; patience, non-judging, beginners mind, acceptance, and letting go (Marriott \& Woolham, 2016).

Mindful individuals are better prepared to cope with complex and conflicting issues and negative arousal (in a cognitive as well as an affective sense) (Marriott \& Woolham, 2016). In this respect, we can say that being mindful is a state of stepping out of our automatic pilot and really begin to live rather than simply exist (Baas, Nevicka, \& Ten Velden, 2014). In mindfulness we learn to be in control of our own minds, instead of letting our minds be in control of us. In other words, we do not ignore distracting thoughts and feelings but we acknowledge and observe them nonjudgmentally as they emerge to create a detachment from them and gain insight and awareness. Mindfulness results in a set of distinct skills, observation (open monitoring), description and accepting without judgment (Baer, Smith, Hopkins, Krietemeyer, \& Toney, 2006; Carmody \& Baer, 2008; Kabat-Zinn, 2010).

Mindfulness is a state of being in control of our minds in order to view present experience from multiple perspectives rather than subjective mono vision/automatic pilot.

Mindfulness and creativity: Previous studies proposed that observation and openness to experience/accepting without judgments that are critical skills of being mindful are strongly related to creative mindset. Observation with openness represents the tendency to view ideas, events, and experiences in a nonjudgmental and interesting manner. It is characterized by active imagination, intellectual curiosity, and a preference for variety (Carson, 2014). Observation with openness is extremely associated with increasing cognitive flexibility (Chambers, Gullone, \& Allen, 2009; Slagter et al., 2007). Namely, there is a greater ease to view and accept alternative approaches to complex problems (Greenberg, Reiner, \& Meiran, 2012) as a result to the inhibition of the automatic responding. In this sense, we can realize that being mindful switches our minds to divergent thinking, as it improves attention and makes it easier to register the novelty and usefulness of ideas. Thus, mindfulness nurtures courage and resilience to accept ambiguity and complexity (Schootstra, Deichmann, \& Dolgova, 2017). As a result of being at the present moment, viewing far from our automated perception, the ability to improvise increases. Improvisation rarely comes from thinking; it is commonly developed from being, observing, and listening in the moment. By being present, improvisers move away from the thoughts in their head to become more aware of their surroundings, gathering full-sensory information that can drive more original, rather than automatic, choices and reactions due to fluency and flexibility that emerge (Leonard, 2016) (Figure 4). 


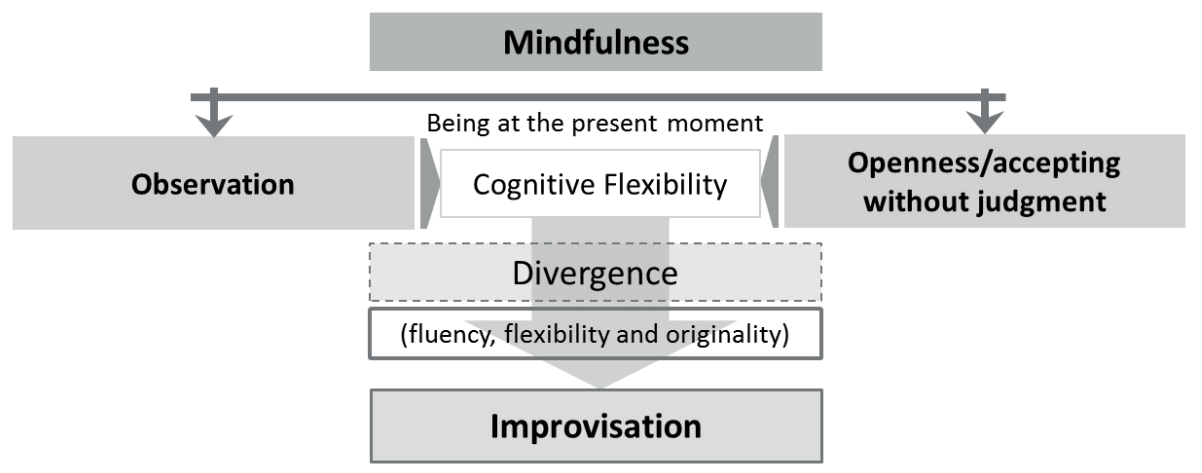

Figure 4. Mindfulness framework for more creative mindset (source: created by author)

\subsection{Improvisation}

The earliest use of improvisation is found in records of a Roman farce performed in 391 BC (Jiménez Marquez, 2014). It is a core technique used by actors at theatres. It outstretches imagination, boosts spontaneity and can result in exceptional and impressive scenes and performances. In fact, improvisation becomes important even in our everyday life. It is relevant when we talk about "Eureka!" moment when someone improvises and repurposes whatever is at hand to solve a problem or to seize opportunity.

Defining improvisation: "Intuition guiding action in a spontaneous way" (Crossan \& Sorrenti, 2005, p. 27) is one of the most accepted definitions of improvisation. To clarify, as stated in Macmillan Dictionary, "to improvise" is to do something without preparing it first, often because the situation does not allow you to prepare (2009-2018). However, improvisation is not absolutely based on intuition, but a skill that can be, or ought to be, learned. It also means to make something from whatever is available, although it is not what you normally use. However, improvisation is considered a general skill that can be pursued in many fields and situation to gain better results. This apparently describes improvisation as a socio-cognitive construct and an unconscious mode of information processing spontaneity (Arshad, 2011).

To understand the essence of improvisation, we should realize the extreme relevance of deferring judgment which is one of the most crucial practices of creativity; nevertheless, it can be a hard behavior to adopt. Once you become aware of your judgment, you will begin to recognize it in yourself, and in others. It is easy to scan, sort, and throw out ideas quickly in order to be efficient, but quick judgment misses possibilities and ultimately stifles creativity (Burnett \& Cabra, 2018). Accordingly, in order to improvise we should learn to defer judgment and this could be achieved by learning how to observe and listen actively; observe and listen to understand; to have the willingness to change, then to accept and build upon not working against. The latter means saying "yes and..." not "yes, but..." (Dugan, 2018).

Improvisation is the ability to observe with all senses actively, to have the power to defer judgment in order to be always in charge to generate/produce fluently without former preparation. 


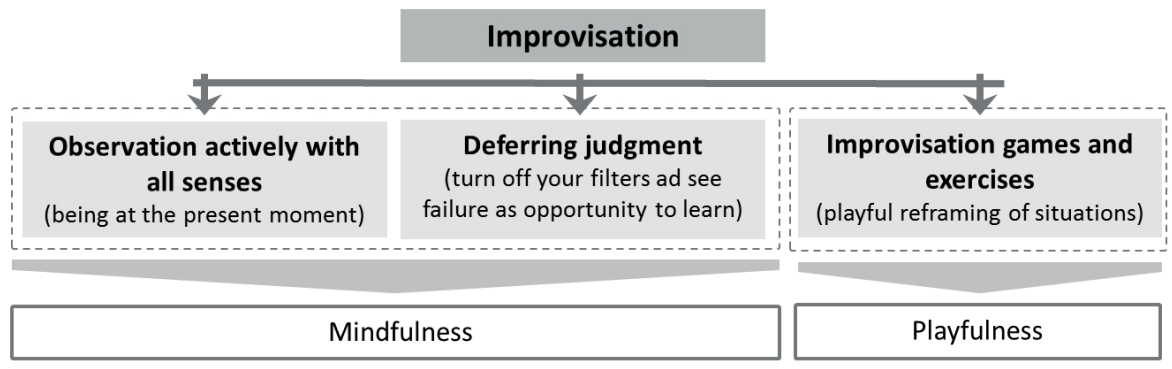

Figure 5. Mindfulness framework for more creative mindset (source: created by author)

Improvisation and creativity: In relation to creativity, improvisation can be defined as the process of creating ideas spontaneously without any planning or refinement (Sowden, Clements, Redlich, \& Lewis, 2015). Creativity process seems as improvised interaction between individuals, thus, it is a key mechanism that enables individuals to maneuver in a context of uncertainty and continuous change. Nevertheless, improvisation cannot be seen as a purely individual activity, but must be understood as a mutually collective activity. Individuals will inevitably be influenced by each other's perspectives and reactions in the present moment (Larsen \& Bogers, 2014). In short, improvisation is an effective tool that develops people's creativity helping them thriving in a complex and unpredictable situation (Ross, 2013) driven by the ability to defer judgment. In this sense, it is important to emphasize that learning and applying the principles of improvisation does not replace the need for preparation and planning. It complements it, since it is a tool that gives you the confidence to respond to unusual situations (McWaters, 2012).

The question here is how to enhance improvisation? We can start learning by applying and practicing specific stuff. Be mindful, be at the present moment, observe, stop, listen and look around. You can do this anywhere. However, we need to remember a very crucial rule; turning off our filters. We must charge forward fearlessly about making mistakes; understand failure as an opportunity to learn. On the other hand, play via games and exercises is also an integral tool to learn and practice the principles of improvisation. Playing creates a joyful climate to apply improvisation without overthinking as it happens in actual world situations. Thus, playing games helps people to train minds to improvise, and hence applying this with ease in the real situations (McWaters, 2012). Recent studies suggest that even a short exposure to improvisation games and activities can develop divergent thinking and creativity (Sowden et al., 2015) (Figure 5).

\section{Sewing dynamics to boost creative mindset}

Crossing literature of playfulness, mindfulness, and improvisation and their relations with creativity, revealed that every single force could affect creativity directly. However, boosting playfulness could affect mindfulness and improvisation and in turn creativity. Furthermore, mindfulness affects creativity in a direct manner and also could support improvisation which consecutively has impact on creative mindset. These findings will be presented comparatively in detail as follows (Table 1, Figure 6). 
Table 1. Traversing interrelations among playfulness, mindfulness, and improvisation for creative mindset (source: created by author)

\begin{tabular}{|c|c|c|}
\hline Playfulness & Mindfulness & Improvisation \\
\hline $\begin{array}{l}\text { Playfulness direct effect on crea- } \\
\text { tive mindset }\end{array}$ & $\begin{array}{l}\text { Mindfulness direct effect on creative } \\
\text { mindset }\end{array}$ & $\begin{array}{l}\text { Improvisation direct ef- } \\
\text { fect on creative mindset }\end{array}$ \\
\hline $\begin{array}{l}\text { Being a function of human devel- } \\
\text { opment: } \\
\text { It affects human abilities to } \\
\text { challenge the status quo not be- } \\
\text { cause it is only a problem but to } \\
\text { reach better conditions (seize an } \\
\text { opportunity). }\end{array}$ & $\begin{array}{l}\text { Improving observation: } \\
\text { It enhances the ability to accept } \\
\text { without judgment. This increases the } \\
\text { cognitive flexibility and inhibits any } \\
\text { automatic responding, hence boost- } \\
\text { ing the divergent thinking. }\end{array}$ & $\begin{array}{l}\text { Deferring judgment/ } \\
\text { saying "yes, and..." } \\
\text { It kindles fluency, } \\
\text { flexibility, and origi- } \\
\text { nality skills needed for } \\
\text { divergence. }\end{array}$ \\
\hline $\begin{array}{l}\text { Creating inspiring press: } \\
\text { It provides different emotional } \\
\text { experience of interest, discovery } \\
\text { and pleasure which introduce } \\
\text { knowledge, and creativity. }\end{array}$ & $\begin{array}{l}\text { Boosting being in control of our } \\
\text { own minds, which results in insight: } \\
\text { It affects coping with complex and } \\
\text { conflicting issues; i.e., being tolerant } \\
\text { for complexity and ambiguity. }\end{array}$ & \\
\hline $\begin{array}{l}\text { Helping to reach self-realization: } \\
\text { It facilitates exploring our pow- } \\
\text { ers. We play to find out what we } \\
\text { can - and cannot - do and to see } \\
\text { if we can extend our capabilities, } \\
\text { which all in turn affect self-con- } \\
\text { fidence. }\end{array}$ & & \\
\hline $\begin{array}{l}\text { Developing mental flexibility } \\
\text { through different play experienc- } \\
\text { es: } \\
\text { It forces our minds to be open } \\
\text { for novelty and tolerant for com- } \\
\text { plexity and ambiguity. }\end{array}$ & & \\
\hline $\begin{array}{l}\text { Playfulness indirect effect on crea- } \\
\text { tive mindset via mindfulness }\end{array}$ & & \\
\hline $\begin{array}{l}\text { Creating a state of mindfulness: } \\
\text { It guides a focus to specific ac- } \\
\text { tivities or goals. This is similar to } \\
\text { be mindful. Being in the present } \\
\text { moment unfolding its possibilities. }\end{array}$ & & \\
\hline $\begin{array}{l}\text { Boosting observation: } \\
\text { It prevents acting on automatic } \\
\text { pilot, which is the most important } \\
\text { skill of mindfulness that is associ- } \\
\text { ated with creativity. }\end{array}$ & & \\
\hline $\begin{array}{l}\text { Playfulness indirect effect on crea- } \\
\text { tive mindset via improvisation }\end{array}$ & $\begin{array}{l}\text { Mindfulness indirect effect on crea- } \\
\text { tive mindset via improvisation }\end{array}$ & \\
\hline $\begin{array}{l}\text { Opening the door for improvisa- } \\
\text { tion: } \\
\text { It puts individuals in unexpect- } \\
\text { ed situations but within playful } \\
\text { press. }\end{array}$ & $\begin{array}{l}\text { Developing the experience of being } \\
\text { with all senses: } \\
\text { It enhances improvisation, as im- } \\
\text { provisation rarely comes from think- } \\
\text { ing and basically emerges from being } \\
\text { in the moment. Improvisers proceed } \\
\text { away from the inner thoughts to } \\
\text { become more aware of the reality. }\end{array}$ & \\
\hline
\end{tabular}




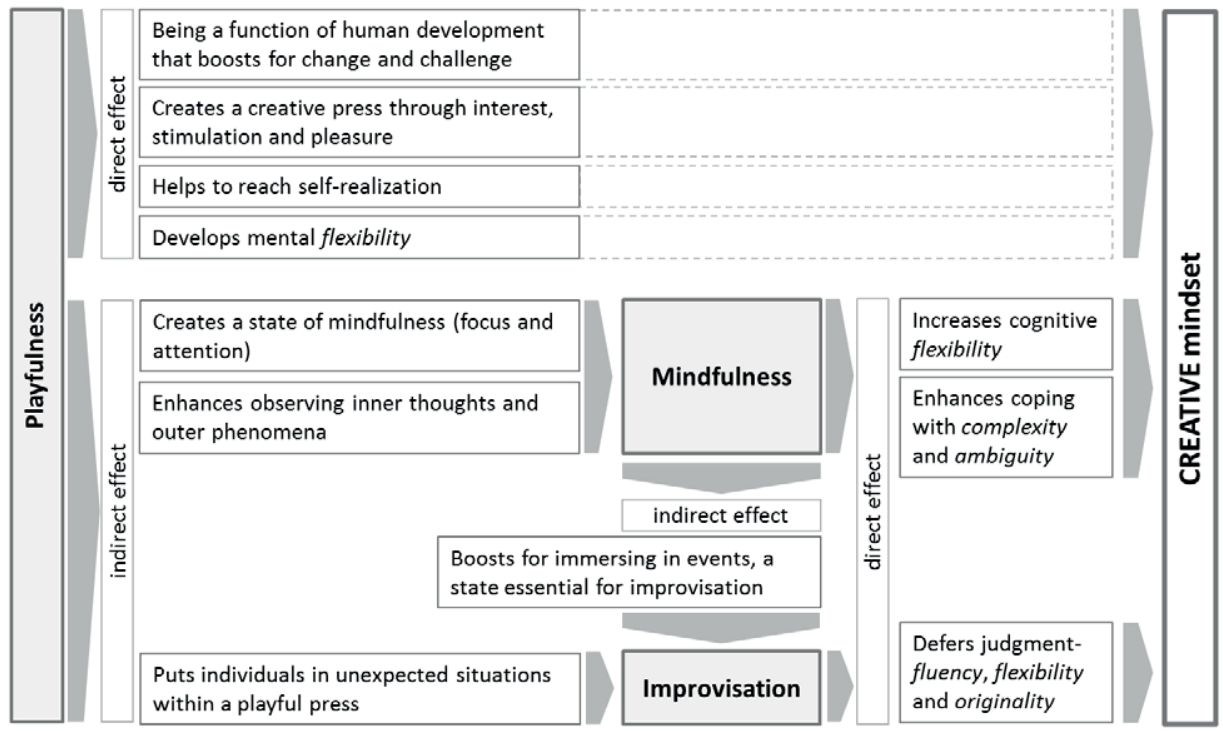

Figure 6. The interrelations among creativity dynamics (source: created by author)

Despite being the master among dynamics, having both direct and indirect effects on creativity, playfulness is not the nearest coat to our creative mindset. In other words, "idea generation" is the essence of any CPS, which is the direct result of improvisation. If we imagine our creative mindset coated in these dynamics, the layers could appear from inside to outside in the following order: improvisation, mindfulness and finally playfulness according to the previous analysis (Figure 7). In brief, creativity emerges from improvisation, but to reach this potential we need to start from playfulness.

Based on these findings and discussion, it can be concluded that playfulness, mindfulness and improvisation are interrelated forces. These forces create "trilateral dynamics" constituting a base towards developing the creative mindset/creative person. Playfulness, mindfulness, and improvisation kindle creativity via developing the basic affective skills for any creative person, the big three. Being open for novelty, tolerant for ambiguity and tolerant for complexity is extremely correlated with acquiring the divergent thinking skills of fluency, flexibility and originality that are thoroughly empowered via these dynamics. Accordingly, the term "trilateral dynamics" can be coined in the field of creativity studies (Figure 8).

\section{Conclusions}

This research focused on creative person as the motor of the 4Ps of creativity - person, press, process, and product. Although they work functionally when they are unified, the 4Ps as gearwheels keep moving just by its incentive component, the "creative person". Based on this fact, the literature in this area, shows that creative person should possess the ability to entertain ideas that may seem wild and risky; deal with uncertainty to avoid jumping to 


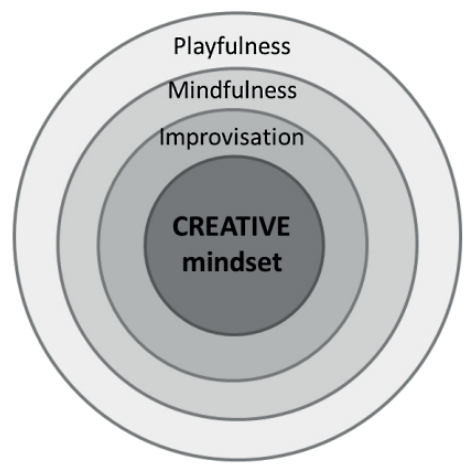

Figure 7. Dynamics layers of creative mindset (source: created by author)

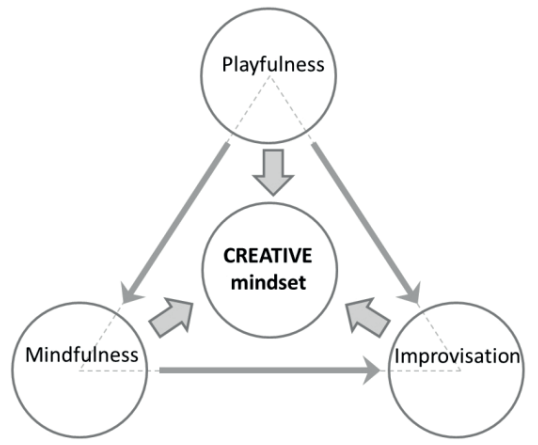

Figure 8. Trilateral dynamics as a foundation for creative mindset (source: created by author)

immature conclusions, and finally stay open without being overwhelmed by the complex issues. Accordingly, this research tried to explore approaches to acquire these skills. The research investigated correlations among playfulness, mindfulness and improvisation as three different experiences/forces mentioned in literature in relation to creativity. The research proved that there are links among these forces. Playfulness can be considered the mother that creates a state for both mindfulness and improvisation. Playfulness affects creativity both directly through practicing specific activities or remodeling any task within a playful mode; and indirectly by affecting both mindfulness and improvisation and, in turn, creativity. Mindfulness also has an impact on creative personality directly through training in a mindful observation, and indirectly through boosting improvisation. These forces when enhanced emphasizing their interrelations, can form a "trilateral dynamics" that acts as a foundation for creative mindset.

\section{References}

Arshad, D. (2011). Understanding organisational improvisation: foundations and performance implications (A Doctoral Thesis). Loughborough University. Loughborough, United Kingdom Retrieved from https://dspace.lboro.ac.uk/dspace-jspui/bitstream/2134/8115/1/THESIS\%20DARWINA\%20 FINAL\%21\%21.pdf

Baas, M., Nevicka, B., \& Ten Velden, F. S. (2014). Specific mindfulness skills differentially predict creative performance. Personality and Social Psychology Bulletin, 40(9), 1092-1106. https://doi.org/10.1177/0146167214535813

Baer, R. A., Smith, G. T., Hopkins, J., Krietemeyer, J., \& Toney, L. (2006). Using self-report assessment methods to explore facets of mindfulness. Assessment, 13(1), 27-45. https://doi.org/10.1177/1073191105283504

Bateson, P., \& Martin, P. (2013). Play, playfulness, creativity and innovation. Cambridge: Cambridge University Press. https://doi.org/10.1017/CBO9781139057691

Bateson, P., \& Nettle, D. (2014). Playfulness, ideas, and creativity: a survey. Creativity Research Journal, 26(2), 219-222. https://doi.org/10.1080/10400419.2014.901091 
Brown, S., \& Vaughan, Ch. (2009). Play: how it shapes the brain, opens the imagination, and invigorates the soul. New York: Avery.

Burnett, C., \& Cabra, J. F. (2018). SUNY: ignite your every day creativity. Divergent thinking, Coursera. Retrieved from https://www.coursera.org/lecture/ignite-creativity/divergent-thinking-RQUN7

Carmody, J., \& Baer, R. A. (2008). Relationships between mindfulness practice and levels of mindfulness, medical and psychological symptoms, and well-being in a mindfulness-based stress reduction program. Journal of Behavioral Medicine, 31, 23-33. https://doi.org/10.1007/s10865-007-9130-7

Carson, Sh. (2014). The impact of mindfulness on creativity research and creativity enhancement. In Ie, A., Ngnoumen, Ch. T., \& Langer, E. J. (Eds.). The Wiley Blackwell handbook of mindfulness (pp. 328-344). Vol. I. Chichester: John Wiley \& Sons, Ltd. https://doi.org/10.1002/9781118294895.ch18

Chambers, R., Gullone, E., \& Allen, N. B. (2009). Mindful emotion regulation: an integrative review. Clinical Psychology Review, 29(6), 560-572. https://doi.org/10.1016/j.cpr.2009.06.005

Crossan, M. M., \& Sorrenti, M. (2005). Making sense of improvisation. In K. N. Kamoche, M. Pina E. Cunha, \& J. Vieira da Cunha (Eds.). Organizational improvisation (pp. 27-48). London and New York: Routledge.

Dugan, M. (2018). Just say yes, know innovation. Retrieved from http://knowinnovation.com/2012/10/ just-say-yes/

Eberle, S. G. (2014). The elements of play: toward a philosophy and a definition of play. Journal of Play, 6(2), 214-233.

Gackenbach, J., \& Bown, J. (2011). Mindfulness and video game play: a preliminary inquiry. Mindfulness, 2(2), 114-122. https://doi.org/10.1007/s12671-011-0049-2

Greenberg, J., Reiner, K., \& Meiran, N. (2012). "Mind the Trap": mindfulness practice reduces cognitive rigidity. PLoS ONE, 7(5), 1-8. https://doi.org/10.1371/journal.pone.0036206

Henricks, Th. S. (2014). Play as self-realization: toward a general theory of play. American Journal of Play, 6(2), 190-213.

Jiménez Marquez, A. (2014). The creative impact of improvisation, boxes and arrows. Retrieved from http://boxesandarrows.com/the-creative-impact-of-improvization/

Jung, C. G. (2016). Psychological types: general description of the types. Eastford, CT: Martino Fine Books. https://doi.org/10.4324/9781315512334

Kabat-Zinn, J. (2010). Wherever you go, there you are: mindfulness meditation in everyday life. New York, Boston: Hachette Books.

Kaufman, J. C., \& Beghetto, R. A. (2009). Beyond big and little: the four c model of creativity. Review of General Psychology, 13(1), 1-12. https://doi.org/10.1037/a0013688

Kumar, M., Roy, S., \& Sameer, A. (2017). Influence of creative thinking and playfulness on creative styles of the individuals. Research into Design for Communities, 2, 465-474. https://doi.org/10.1007/978-981-10-3521-0_40

Kuschner, D. (2010). Book Review. Stuart Brown, Christopher Vaughan. Play: How It Shapes the Brain, Opens the Imagination, and Invigorates the Soul. American Journal for Play, 2(3), 374-376.

Larsen, H., \& Bogers, M. (2014). Innovation as improvisation in "The Shadow". Creativity and Innovation Management, 23(4), 386-399. https://doi.org/10.1111/caim.12067

Leonard, K. (2016). Mindfulness and improvisation, LinkedIn. Retrieved from https://www.linkedin. $\mathrm{com} / \mathrm{pulse} /$ mindfulness-improvisation-kelly-leonard

Lieberman, J. N. (1977). Playfulness: its relationship to imagination and creativity. Series: Educational Psychology Series. New York: Academic Press, Inc.

Macmillan Dictionary. (2009-2018). Improvise - definition and synonyms. Retrieved from https://www. macmillandictionary.com/dictionary/british/improvise 
Mainemelis, Ch., \& Ronson, S. (2006). Ideas are born in fields of play: towards a theory of play and creativity in organizational settings. Research in Organizational Behavior, 27, 81-131. https://doi.org/10.1016/S0191-3085(06)27003-5

Marriott, S., \& Woolham, J. (2016). Mindfulness practice, creativity and innovation. Retrieved from http:// mindfulenhance.org/wp-content/uploads/2015/06/Mindfulness-creativity-and-innovation.pdf

McWaters, V. (2012). Unpacking applied improv. Beyond the edge. Retrieved from http://vivmcwaters. com.au/2012/06/04/unpacking-applied-improv/

Miller, B., Vehar, J., Firestien, R., Thurber, S., \& Nielsen, D. (2011). Creativity unbound: an introduction to creative problem solving. Williamsville, NY: Innovation Systems Group.

Murdock, M. C., Burnett, C., \& Mance, M. (2008). The Big Three - understanding and applying basic affective skills that underlie CPS: the thinking skills model. Retrieved from https://d396qusza40orc. cloudfront.net/creative/The\%20Creative\%20Person/FinalBigThreeMOOC.pdf

Nairn, R. (1999). Diamond mind: a psychology of meditation. Boston, MA: Shambhala Publications, Inc.

Positive Psychology Program. (2017). History of mindfulness: from East to West and from religion to science. Retrieved from https://positivepsychologyprogram.com/history-of-mindfulness/

Rhodes, M. (1961). An analysis of creativity. The Phi Delta Kappan, 42(7), 306-310.

Ross, K. (2013). All about improv, applied improv, creativity, play, innovation... Part 1, spotlight on marketing. Retrieved from http://www.kayross.com/blog/2013/04/26/all-about-improv-applied-improvcreativity-play-innovation/

Schootstra, E., Deichmann, D., \& Dolgova, E. (2017). Can 10 minutes of meditation make you more creative?. Harvard Business Review. Retrieved from https://hbr.org/2017/08/can-10-minutes-ofmeditation-make-you-more-creative

Slagter, H. A., Lutz, A., Greischar, L. L., Francis, A. D., Nieuwenhuis, S., Davis, J. M., \& Davidson, R. J. (2007). Mental training affects distribution of limited brain resources. PLoS Biology, 5(6), 12281235. https://doi.org/10.1371/journal.pbio.0050138

Sowden, P. T., Clements, L., Redlich, Ch., \& Lewis, C. (2015). Improvisation facilitates divergent thinking and creativity: realising a benefit of primary school arts education. Psychology of Aesthetics, Creativity and the Arts, 9, 128-138. https://doi.org/10.1037/aca0000018

Sternberg, R. J. (2006). The nature of creativity. Creativity Research Journal, 18(1), 87-98. https://doi.org/10.1207/s15326934crj1801_10

West, S. E., Hoff, E., \& Carlsson, I. (2016). Play and productivity: enhancing the creative climate at workplace meetings with play cues. American Journal of Play, 9(1), 71-86.

\title{
TRIŠALĖ KŪRYBIŠKUMO DINAMIKA: ŽAIDYBIŠKUMAS, SĄMONINGUMAS IR IMPROVIZACIJA
}

\section{Doaa KAMALELDIN HASSAN}

\begin{abstract}
Santrauka
Kaip parodė naujausi tyrimai, kūrybiškumas jau nebėra pasirinkimo alternatyva jis išties svarbus kasdieniam mūsų gyvenimui. Iš tikrųjų kūrybiškumas - tai bendra visuma, kurią sudaro keturios susipynusios gijos: kūrybiška asmenybè, kūrybinè jèga, kūrybinis procesas ir kūrybinis produktas. Nepaisant to, kūrybiška asmenybè gali būti laikoma šių sujungtų krumpliaračių varomąja jèga. Kaip aptarta literatūroje, kūrybiška asmenybè turi būti atvira naujovems, tolerantiška kompleksiškumui ir dviprasmybėms, tačiau čia keliamas klausimas - kaip išugdyti šias savybes. Šia pra-
\end{abstract}


sme žaidybiškumo, sąmoningumo ir improvizacijos problemos gali būti glaudžiai susijusios ir turi galimybę atsakyti ị tokị klausimą. Tiesą sakant, šios temos buvo gvildentos daugelyje tyrimų, susijusių su kūrybiškumu, tačiau nepakanka tų tyrimų, kuriuose jos būtų siejamos vienos su kitomis, i.e. žaidybiškumas ir sąmoningumas, sąmoningumas ir improvizacija ar improvizacija ir žaidybiškumas. Taigi šiame tyrime, kaip indèlyje ị kūrybos psichologijos sriț̣, teigiama, kad šios trys kūrybiškos asmenybės patirtys ar galios koreliuoja tarpusavyje. Taigi šio tyrimo tikslas - išnagrinèti šiuos tarpusavio ryšius, kurie, jei būtų skatinami, galètų turèti ịtakos kūrybiškos asmenybès savybėms. Metodologija grindžiama indukciniu argumentavimu dviem etapais: pirma, analizuojant literatūrą, skirtą žaidybiškumui, sąmoningumui ir improvizacijai bei jų sąsajoms su kūrybiškumo tyrimais; antrasis etapas vyksta, skersai išilgai nagrinejjant šias tris dalis, susiejant jas tarpusavyje siekiant sukurti šių trijų galių sampyną, kad jos funkcionuotų dinamiškai, kūrybišką mąstyseną pakylèdamos ị aukštesnị lygị.

Reikšminiai žodžiai: kūrybiška mąstysena, kūrybiška asmenybė, kūrybiškumas, improvizacija, sąmoningumas, žaidybiškumas. 